then I have never been able to keep my balance, so I'll be walking to work on National Cycle To Work Day'. Another initiative, 'Don't Choke Britain 97' is viewed, among other things, as 'vital in changing people's attitudes across the country about realistic alternatives to the car'. A third, Walk to School Week, includes figures provided, I suspect, by Ian Roberts. These compare the rates of 8 year olds who walked to school without an adult in $1971 v$ the present ...87\% $v 11 \%$.
Finally, in passing, it is interesting that road casualty figures for the UK, comparing 1996 with 1995, show that child casualties rose by $2 \%$.

We await further developments in the UK with great expectations. If these are fulfilled, they will provide grounds for trying to persuade our own leaders to follow the UK's example. Having a Minister of Public Health is a superb way of responding wisely to injury prevention challenges.

\title{
A tragedy for us all
}

The death of Diana, Princess of Wales, is a blow to all of us for many reasons. Above all there is the human tragedy, especially for her children. Her work to bring the world's attention to the obscenity of landmines as a tool of war was a great accomplishment. Few would deny that only someone with her profile could have achieved so much. The conference in Norway was on the verge of agreeing to this ban on the very day of her death.

As well as her loss to this cause - a cause that I assume all readers of this journal endorse - she was the former Patron of the Child Accident Prevention Trust. Although she recently left this role, her support was important in gaining for the Trust the recognition it so fully deserves.
Finally, we cannot ignore the manner of her death: if anyone needed to be reminded of the horrors of speeding, drunk driving, or the failure to wear seatbelts, no matter what the compounding role of the press may or may not have been, this event should hammer these messages home. Just as we pray that all untimely deaths carry some good with them, so might we reasonably expect that the Princess of Wales' death will accelerate the agreement to ban landmines and to enforce stricter controls against drunk driving and speeding.

Our hearts go out to William and Harry, the Princess's children.

\section{Reviewers in this volume}

Again, I must offer my most sincere thanks to the anonymous reviewers listed below. Special thanks to everyone whose wisdom and helpful comments have made this journal so scientifically worthy and so readable. Without such referees, this journal could not have achieved such high standards. Their usually speedy, thoughtful, and often highly detailed comments, are deeply appreciated by the editors, and, I hope, by most authors. Each of those listed below have reviewed one or more manuscripts this past year; several, especially, members of the editorial board, have reviewed many. I am deeply grateful to all.

I B PLESS Editor

\begin{tabular}{|c|c|c|c|}
\hline Phyllis Agran & Yossi Harel & James Nixon & Mark Stevenson \\
\hline Cheryl Alexander & Mike Hayes & Terry Nolan & Lorna Stewart \\
\hline Ken Asher & Ralph Hingson & Robyn Norton & David Stone \\
\hline Jean Athey & Fred Homer & Leonora Olson & Dean Stueland \\
\hline Malcolm Barrow & Tsung-Hsueh Lu & John Pearn & Leif Svanström \\
\hline Peter Barss & Hugh Jackson & Joss Pedder & Steve Teret \\
\hline David Bass & Murray Katcher & Lisette Peterson & Elizabeth Towner \\
\hline Joel Bass & James King & Eleni Petridou & Anne Tursz \\
\hline Ginette Beaulne & Jonathan Kotch & Katharina Purtscher & Dirk van Aken \\
\hline Mary Benedict & Michael Kramer & Ray Ranson & Rene Verreault \\
\hline Andy Benson & Jess Kraus & Anne Riley & Graham Vimpani \\
\hline Polly Bijur & Rajan Krishnan & Fred Rivara & Peter Vulcan \\
\hline David Chalmers & John Langley & Ian Roberts & Julian Waller \\
\hline Lisa Cohen & Gary Lapidus & Kenneth Roberts & Sean Walsh \\
\hline Sonya Corkum & Charles Larson & Carol Runyan & Harold Weiss \\
\hline Robert Dershewitz & John Leblanc & Peter Scheidt & Brian Wiersema \\
\hline Geoff Dougherty & Barbara Lee & Lothar Schelp & Modena Wilson \\
\hline Caroline Finch & Bernard Leveque & Rick Schieber & Diana Winn \\
\hline Lois Fingerhut & Colin Macarthur & Melvin Schloss & Flaura Winston \\
\hline Sue Gallagher & David McGillivray & Ian Scott & Garen Wintemute \\
\hline David Geddis & Elizabeth McLoughlin & Yvonne Senturia & Tatsuhiro Yamanaka \\
\hline Rosa Gofin & James Mercy & Jo Sibert & Janice Yuwiler \\
\hline Philip Graitcer & Angela Mickalide & David Sleet & Joseph Zanga \\
\hline Laurence Green & Ted Miller & Lee Soderstrom & Anthony Zwi \\
\hline David Grossman & Michael Moffatt & Lorann Stallones & \\
\hline Bernard Guyer & Dinesh Mohan & Rick Stanwick & \\
\hline
\end{tabular}

